\title{
AKTIIVISEN KANSALAISUUDEN MAHDOLLISUUDET KOTOUTTAMISTYÖN ULKOISTEN EHTOJEN JA MAAHANMUUTTAJIEN TARPEIDEN RISTIPAINEISSA
}

Kati Turtiainen: YTT, Jyäskylän yliopisto, Kokekolan yliopistokeskus Chydenius

Tuomo Kokkonen: YTT, Jyväskylän yliopisto, Kokkeolan yliopistokesk.us Cbydenius

Katri Viitasalo: YTT, Jvä̈skylän yliopisto, Kokkeolan yliopistokesk.us Chydenius

kati.turtiainen@chydenius.fi; tuomo.kok.konen@chydenius.fi;

katri.viitasalo@chydenius.fi

Janus vol. 26 (4) 2018, 343-360

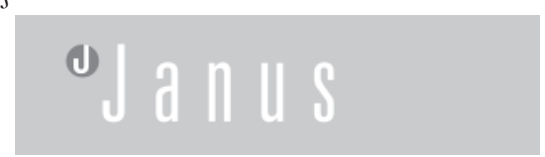

Tiivistelmä

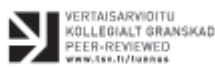

Nykyisessä poliittisessa keskustelussa aktiivinen kansalaisuus ymmärretään usein kapeasti työkansalaisuutena. Artikkelissa analysoidaan, miten aktiivinen kansalaisuus rakentuu kotouttamistyön rakenteellisten ehtojen ja maahanmuuttajien tarpeiden huomioimisen ristiriidassa. Teoreettisesti nojaudutaan Amartya Senin toimintamahdollisuuksien teoriaan, joka painottaa erilaisten kyvykkyyksien sekä autonomisten toimintamahdollisuuksien merkitystä aktiivisessa kansalaisuudessa. Tuloksena havaitaan, että ammattilaisten näkemyksissä painottuu ristiriita järjestelmän tarpeille rakentuvan työkansalaisuuden ja kotoutujien autonomiaa tukevien toimintamahdollisuuksia vahvistavan työn välille. Myös kotiäitien perheasemaan perustuva kansalaisuus on erityisen vaikeasti saavutettavissa. Lopputuloksena on, että järjestelmän tarpeille rakennettu maahanmuuttajien sopeuttaminen kääntyy itseään vastaan, sillä yksilöiden tarpeet eivät rakennu ulkoisten määrittelyjen varaan. Lopulta yksilöllisten tarpeiden tunnistamattomuus ja huomiotta jättäminen passivoi maahanmuuttajaa.

\section{JOHDANTO}

Kansalaisuus ei ole abstrakti universaali käsite vaan sille annetut merkitykset heijastelevat kunkin yhteiskunnan historiaa sekä sosiaalisia ja institutionaalisia oloja (Marshall 1992, 18; Turner 2001; Lister 2007, 2).Viime vuosikymmeninä tärkeimpiä eurooppalaisten yhteiskuntien kansalaisuutta muokanneita kehityskulkuja ovat olleet pyrkimys muokata kansalaisuudesta yhä aktiivisempaa (Johansson \& Hvinden 2007; Evers \& Guillemard 2013), sekä maahanmuuton ja vähemmistöjen aseman huomioiminen (Kymlicka \& Norman 1994; Isin \& Turner 2007). Artikkelimme osallistuu näistä muutoksista käytävään keskusteluun tarkastelemalla sitä, miten aktiivista kansalaisuutta rakennetaan kotouttamistyön rakenteellisten ehtojen ja maahanmuuttajien tarpeiden välisessä ristipaineessa. Tarkastelu pohjautuu Länsi-Suomessa toimiville kotouttamistyön ammattilaisille tehtyihin haastatteluihin.

1990-luvun alun laman jälkeen Suomessa käytyjä kansalaisuutta koskevia poliittisia kamppailuja on määrittänyt pyrkimys kansantalouden tehostamiseen (Eskelinen 2017). Tehostamisprosessin myötä sosiaalipolitiikassa pohjoismaisen hyvinvointivaltion perinne on saanut antaa tilaa budjettikurille, leikkauksille sekä aikaisemmin julkisesti tuotettujen palveluiden markkinaistamiselle, minkä seurauksena myös kansalaisuutta muovaavien politiikkojen painopisteet ja päämäärät ovat muuttu- 
neet. Hyvinvointivaltion kultakaudella kansalaisuutta tarkasteltiin sosiaalisista näkökohdista ja yhteisen edun kannalta. Hyvinvointivaltion kriitikoiden mukaan yksilön suhde kansalaisuuteen ymmärrettiin tuolloin passiivisena $\mathrm{ja}$ siinä korostui liialti etuisuuksien hyödyntäminen. Nykyhetkelle ominainen "hyvinvointivaltion uusi politiikka" puolestaan korostaa kansalaisuudessa yksilön aktiivista toimintaa ja aivan erityisesti tarvetta hankkia toimeentulo työllä sosiaaliturvan hyödyntämisen sijaan (Heiskala 2006; Evers \& Guillemard 2013, 10-18; Julkunen 2017, 314-354).

Näkemyksemme mukaan aktiivinen kansalaisuus tarkoittaa mahdollisuutta omien tavoitteiden mukaiseen autonomiseen toimintaan. Se sisältää työllistymisen lisäksi muutkin elämänalueet, kuten vanhemmuuden ja vapaa-ajan (Lister 2007; Erel 2011). Pidämme tärkeinä myös lisätä kansalaisten osallistumista kansalaistoimintaan ja poliittiseen päätöksentekoon sekä heidän mahdollisuuksiaan vaikuttaa julkisessa hallinnossa ja palvelujärjestelmässä (Sen 1993). Käytännössä aktiivinen kansalaisuus on kuitenkin ennen kaikkea lujittanut kansalaisuuden yhteyttä markkinoihin ja työntekoon, eli se on tuottanut niin sanottua workfare- tai työkansalaisuutta (Kantola \& Kananen 2013; Julkunen 2017, 72-73). Sosiaalipolitiikan kannalta on merkittävää, että monien huono-osaisten väestöryhmien kohdalla muutos on tarkoittanut kansalaisvelvollisuuksia korostumista kansalaisoikeuksien sijaan (Kotiranta 2008; Närhi \& Kokkonen 2014; Kokkonen 2016; Kivipelto 2018). Oletamme tämän kehityksen heijastuvan myös ko- touttamistyöhön (myös Suurpää 2002, 16).

Kotouttamistyö on halkaistu institutionaalisesti kahtia yhtäältä työkansalaisuuden rakentamiseksi ja toisaalta muille elämänalueille ulottuvaan työhön (Vuori 2015). Laissa kotoutumisen edistämiseksi (1386/2010, myöhemmin kotolaki) määritetään, että työvoimahallinto vastaa työmarkkinoille tähtäävistä maahanmuuttajista. Kuntien tehtävänä taas on työmarkkinoiden ulkopuolelle jäävien henkilöiden, kuten lasten, vanhusten, perhevapaalla olevien vanhempien ja pitkäaikaissairaiden kotouttaminen. Kun kotouttamistyötä tarkastellaan aktiivisen kansalaisuuden näkökulmasta, keskiössä on maahanmuuttajien ohjaaminen työelämään. Kuntien tekemä kotouttamistyö puolestaan keskittyy työmarkkinoiden ulkopuolella olevien maahanmuuttajien arkeen. Lain piirissä ovat kaikki maahanmuuttajat kolmen ensimmäisen Suomessa asumisvuoden ajan. Kotoutumisaikaa voidaan myös pidentää viiteen vuoteen, mikäli henkilö on perhevapaalla tai hänellä on erityistarpeita, kuten esimerkiksi lukuja kirjoitustaidon saavuttaminen.

Kotolain lisäksi yhdenvertaisuuslaki (1325/2014) ja laki vähemmistövaltuutetusta (751/2011) sitovat viranomaisten toimintaa ja jälkimmäinen myös työnantajia. Näiden lakien tavoitteena on poistaa syrjintään perustuva eriarvoisuus (ks. Kerkkänen 2008, 6).Viime aikoina myös oleskelulupia säätelevä maahanmuuttopolitiikka (ulkomaalaislaki 301/2004) on korostunut liittyen perheenyhdistämiseen sekä turvapaikanhakijoiden ja paperittomien oleskelulupiin. Myös kunnat ovat linjanneet paperittomille tarjottavia palveluita. 
Juridinen Suomen kansalaisuus puolestaan määritellään kansalaisuuslaissa (359/2003).

Ymmärrämme maahanmuuttajien kotoutumisen eri elämänalueille liittyvinä aktiivista kansalaisuutta vahvistavina sekä kotoutujien institutionaalisissa ja muissa arkisissa suhteissa tapahtuvina arjen kansalaisuuden tekoina (Isin 2008; Vuori 2012; 2015). Aktiivisen kansalaisuuden tarkastelussamme nojaudumme Amartya Senin (1993) toimintamahdollisuuksien teoriaan, joka painottaa erilaisten kyvykkyyksien sekä autonomisten toimintamahdollisuuksien merkitystä aktiivisen kansalaisuuden ymmärtämisessä. Analysoimme kotouttamistyön ammattilaisten haastatteluissa rakentuvaa jännitettä kotouttamistyön ulkoisten ehtojen ja mahanmuuttajien tarpeiden huomioimisen välillä. Emme analyysissämme erottele pakkoja vapaaehtoisen muuton kautta tulleita maahanmuuttajia, koska ammattilaisten haastatteluissa nousi esille käsityksiä kaikkien muuttajien kotoutumisen mahdollisuuksista. On kuitenkin syytä huomioida, että haastateltavat työskentelevät pääasiassa pakkomuuttajille suunnatuissa kotouttamispalveluissa. Pakkomuuttajilla tarkoitamme pakolaisena, turvapaikanhakijana tai ihmiskaupan uhrina Suomeen tulleita henkilöitä (esim. Turton 2003).

\section{KOTOUTUMISESTA JA KOTOUTTAMISESTA AKTIIVISEN KANSALAISUUDEN MAHDOLLISTAJANA}

Seuraavassa tarkastelemme tutkimustehtävän kannalta merkityksellisiä kotouttamiseen ja kotoutumiseen liittyviä tutkimuksia. Saukkosen (2013) mukaan kotoutuminen tarkoittaa prosessia, jossa maahanmuuttaja löytää paikkansa yhteiskunnassa. Näin tapahtuu riippumatta kotoutumiseen käytettävästä ajasta ja lainsäädännöstä. Maahanmuuttajien työllistymisen tutkimus on osoitus siitä, että kotoutumista on syytä tarkastella pitkällä aikajänteellä. Esimerkiksi Linnanmäki-Koskela (2010) toteaa, että sekä vapaaehtoisesti että pakolaisina tulleiden maahanmuuttajien työllistymisasteen merkittävä kohoaminen tulee näkyviin, kun työllistymistä seurataan pitemmällä aikavälillä.

Kansalaisuutta koskevassa keskustelussa on kiinnitetty huomiota siihen, että aktiivinen kansalaisuus ymmärretään usein varsin kapeasti kiinnittyneenä työkansalaisuuden ideaaliin. Vastaava painotus on havaittu myös suhteessa kotouttamispolitiikkaan ja sen käytäntöihin (Suurpää 2002; Kerkkänen 2008). Tästä on seurauksena muuan muassa se, että perheiden tarpeet eivät kotouttamiskäytännöissä saa riittävästi huomiota (esim. Nordberg 2015). Myös perheenyhdistämisen mahdollisuuksien kiristyminen tulee näkyviin kotoutumisessa. Raskin ym. (2016) mukaan primääriperheestä erossaololla on yhteys maahanmuuttajien kotoutumiseen. Erossaolo voi lisätä yksinäisyyttä ja työttömyyttä sekä vaikeuttaa kielitaidon kehittymistä. Tutkimuksissa onkin todettu (esim. Nickerson ym. 2010; Wilmsen 2013), että perheestään erossa asuvat pakolaiset oireilevat psyykkisesti yleisemmin kuin perheensä kanssa samassa maassa asuvilla henkilöt.

Tarkastelussamme keskeisiä ovat sellaiset kansalaisuutta tukevat teot, jotka pohjaavat kotoutujien tarpeiden ja kyvykkyyden tunnistamiseen. Tutkijat 
ovat kiinnittäneet huomiota siihen, että maahanmuuttajien henkilökohtaisia ominaisuuksia ja tarpeita ei aina tunnisteta tai ne tunnistetaan väärin (esim. Pyykkönen 2007; Alitolppa-Niitamo 2005; Turtiainen 2012). Niiden sivuuttaminen voi johtaa pitkäaikaiseen hankalaan riippuvuuteen uuden yhteiskunnan tuesta. Tämä näyttäytyy muuan muassa siten, että autonomia ei toteudu vaan käytännön asioiden hoitaminen ja omaa elämää koskeva päätöksenteko jää viranomaisten tehtäväksi (Turtiainen 2011). Sotkasiira (2018b, 48) ehdottaa, että palvelujärjestelmässä kotoutujiin suhtauduttaisiin yhtä aikaa sekä kyvykkäinä että erityisellä tavalla haavoittuvina yksilöinä.

Maahanmuuttajien kykyjen ja osaamisen tunnistamisen haasteita on tutkittu muun muassa Suomen somalien yhteisössä (Sotkasiira 2018a). Tutkijat ovat havainneet, että vaikka Suomen somaleja pidetään tilastojen mukaan yhtenä heikoimmin integroituneista maahanmuuttajaryhmistä, heillä on paljon aloitteellisuutta, joka jää näkymättömäksi suomalaisessa yhteiskunnassa (Pirkkalainen ym. 2016). Aloitteellisuuden ja kykyjen tunnistamattomuus tulee esille myös Sotkasiiran $(2018 b, 2016)$ kotouttavaa työtä tekevien ammattilaisten haastatteluissa (myös Nordberg 2015). Tutkijoiden mukaan sekä politiikan että käytäntöjen tasolla ei huomioida riittävästi kotoutujien jo olemassa olevaa kyvykkyyttä. Autonomian tukemisen ja yksilöllisten kotoutumispolkujen sijaan kotoutujien on usein tyydyttävä ryhmänä tarjottaviin palveluihin.

Yksilöllisten tarpeiden ja toisaalta kyvykkyyden tunnistamattomuus saattaa kotouttamistyössä johtaa tulkintoihin, jotka työntävät maahanmuuttajat marginaaliin. Yksilöllisiin tarpeisiin vastaamisen sijaan ammattilaiset saattavat kulttuuristaa tai rodullistaa maahanmuuttaja-asiakastaan. Kulttuuristaminen tarkoittaa tarpeiden tai ihmisten ominaisuuksien tulkitsemista kulttuurin kautta ikään kuin valmiiksi "tuotuina" (Keskinen 2012) ja rodullistaminen puolestaan sitä, että biologisiin piirteisiin tai kulttuuritaustaan liitetään odotuksia tietynlaisesta käyttäytymisestä (esim. Keskinen 2017; Hiitola \& Peltola 2018). Peltola (2014) osoittaa, että etenkin muslimimaahanmuuttajien epätasa-arvon kokemukset tulkitaan usein liittyviksi intiimille alueelle, perheen sisäisiin valtasuhteisiin. Miesten, naisten ja lasten toimintaa, yhteiskunnallista asemaa ja tasa-arvon mahdollisuuksia eivät kuitenkaan rajaa vain perhesuhteet, vaan tärkeältä osaltaan myös suomalaisen yhteiskunnan rakenteet ja globaali eriarvoisuus.

\section{KANSAlaisuUden TEOT AUTONOMIAN JA SELONTEKOVELVOLLISUUDEN JÄNNITTEESSÄ}

Tarkastelemme kotouttamistyötä ja kotoutumista palvelujärjestelmän sisällä tapahtuvina aktiiviseen kansalaisuuteen tähtäävinä tekoina (Vuori 2012). Konkreettisesti kotouttamistyö voi olla esimerkiksi tiedon jakamista, ohjausta, psykososiaalista tukea, sosiaalisten oikeuksien välittämistä, kielellistä tukea, fyysistä huolenpitoa, kulttuuristen kohtaamisten järjestämistä sekä yhteiskunnallista vaikuttamista (emt.).

Onnistunut kotoutuminen viittaa tässä toimintamahdollisuuksien vahvistumiseen (Sen 1993) ja sen myötä kaikilla elämän osa-alueilla rakentuvaan aktii- 
viseen kansalaisuuteen. Toimintamahdollisuudet paikantuvat maahanmuuttajan ja yhteiskunnan välisiin suhteisiin. Amartya Senin (emt., 31) mukaan toimintamahdollisuuksissa on kyse "yksilön kykyisyydestä saavuttaa arvostamansa toiminta". Mahdollisuudet toimia ja mahdollisuuksien vapaudet konkretisoituvat siinä, mitä ihminen saavuttaa sekä siinä, mitä vaihtoehtoja ihmisellä on valittavanaan (Sen 1992). Ihminen tarvitsee kykyä itsereflektioon, kykyä toimia aktiivisesti sekä kykyä tehdä päätöksensä vapaasti sekä valita vaihtoehdot arvostamansa ja tavoittelemansa elämän puolesta. Institutionaalisten ja muiden arkisten suhteiden tarjoamat vapaudet toimia autonomisesti paikantuvatkin juuri yksilökohtaisiin, vaihtoehtoisiin mahdollisuuksiin. (Gateley 2014,5 .)

Yksilökohtainen autonomia ymmärretään universaalina perustarpeena (Aaltio 2013, 60; Doyal \& Gough 1991; Gateley 2014). Autonomia puolestaan on Doyalin ja Goughin (1991) mukaan sidoksissa ihmisen ymmärrykseen, mielenterveyteen ja ulkoisiin olosuhteisiin. Ymmärryksellä tarkoitetaan kognitiivisia opetuksen kautta saatuja taitoja ihmisestä itsestään ja kulttuuristaan sekä häneen kohdistuvista kulttuurisista odotuksista. Mielenterveyteen liittyvällä emotionaalisella autonomialla tarkoitetaan henkilön riittävää kapasiteettia muodostaa tavoitteita sekä riittävää luottamusta toimia yhteisössä ja vuorovaikutuksessa toisten kanssa. Lisäksi tulisi olla kyky nähdä tekonsa itsensä eikä jonkun toisen tekeminä sekä ymmärrystä toimintansa rajoista ja vastuuta omasta toiminnasta. Näin ollen emotionaalinen ja kognitiivinen kyvykkyys kietoutuvat toisiinsa. (Emt.; Aaltio 2013, 61.)

Myös ulkoiset olosuhteet selittävät autonomiaa (Doyal \& Gough 1991). Ammattilaiset osallistuvat toimintakyvyn ulkoisten edellytysten ja oikeuksien toteutumiseen, institutionaalisiin käytäntöihin ja konkreettiseen asiakassuhteen luomiseen. Perusautonomialla tarkoitetaan mahdollisuutta osallistua yhteiskunnan toimintaan, kuten omia asioita koskevaan päätöksentekoon (Aaltio 2013). Aaltio (emt., 62-63) nostaa perusautonomian rinnalle kriittisen autonomian käsitteen, jolla hän tarkoittaa kyvykkyyttä tuoda esille olemassa olevien vaihtoehtojen lisäksi erilaisia näkökulmia ja tavoitella uusia päämääriä. Kriittisen autonomian toteutuminen edellyttää oman ja muiden kulttuurien kriittistä tarkastelua. Oikeuksien toteutumisen lisäksi juuri todelliset ulkoiset toimintamahdollisuudet erottavat Aaltion (emt., 62) mukaan perusautonomian ja kriittisen autonomian toisistaan. Kriittisen autonomian saavuttamisen edellytys on, että henkilöt ymmärtävät eri kulttuureja siinä määrin, että he voivat arvioida niitä kriittisesti ja tehdä valintoja erilaisten kulttuuristen elämäntapojen välillä.

Kotoutujien tarpeille perustuva, autonomisia toimintamahdollisuuksia vahvistava kotouttamistyö saattaa näyttäytyä jännitteisenä sosiaalityön tutkimuksessa huomiota saaneen ja organisaatioiden tarpeille perustuvan selontekovelvollisuuden (accountability) kanssa (esim. Juhila 2009, 308-309). Käsitteenä selontekovelvollisuus kytkeytyy läheisesti lainsäädäntöön ja ammattietiikkaan. Erityisesti työkäytäntöihin liittyvät ristiriidat synnyttävät 
työntekijöiden selontekovelvollisuuden. He tekevät selkoa toiminnastaan muun muassa palveluiden käyttäjille, työnantajille, yhteistyökumppaneille ja päättäjille. Tarkastelumme kannalta on oleellista se, että kotoutumispalveluiden käyttäjien ja työorganisaatioiden aktiiviseen kansalaisuuteen liittyvät selontekovelvollisuudet ovat ristiriidassa keskenään. Näin ollen ammattilaisen työtä voivat määrittää asiakkaiden tarpeiden sijaan rakenteiden tarpeet. Lisäksi sosiaalityön tutkijat (esim. Banks 2007; Juhila 2009) ovat nostaneet esille käsitteen uusi selontekovelvollisuus, jolla tarkoitetaan sitä, että palveluilla tulisi olla ikään kuin vähimmäisvaatimukset. Mikäli nämä vaatimukset eivät toteudu, asiakas voi valittaa asiasta. Toiminta perustuu tällöin tarkkoihin ohjeistuksiin, joiden noudattaminen mitoittaa työssä onnistumista joskus jopa asiakkaiden tarpeille perustuvan työotteen ja onnistuneen vuorovaikutuksen kustannuksella. Tässä artikkelissa (uusi) selontekovelvollisuus auttaa jäsentämään ulkoisten ehtojen varaan rakentuvaa kotouttamistyötä. Samalla se tekee näkyviksi ristiriidat kotouttamistyön mahdollisuuksissa tukea perus- ja kriittistä autonomiaa, joille kotoutujien aktiivinen kansalaisuus voisi rakentua.

\section{Aineisto Ja SEN ANALYysi}

Tutkimuksen aineisto kerättiin kotouttamiseen liittyvässä kehittämishankkeessa vuosina 2016-2017 kahdessa Länsi-Suomen alueelle sijoittuvassa makunnassa. Haastattelimme kotouttavaa työtä tekeviä viranomaisia ja maahanmuuttajien kotouttamiseen liittyvissä hankkeissa työskentelevïa ammattilaisia. Haastattelut olivat osa laa- jempaa kotouttamiseen liittyvää kehittämis- ja tutkimustyötä. Haastateltavat edustivat kattavasti kyseisten alueiden kotouttamistyön ammattilaisia. Mukana oli sekä viranomaisten että järjestöjen kotouttamistyötä tekeviä, mutta emme tässä artikkelissa erottele heitä toisistaan, vaan puhumme heistä yhteisesti kotouttamistyön ammattilaisina. Emme myöskään identifioi tarkemmin hanketta tai haastateltavia tunnistamattomuuden säilyttämiseksi. Haastateltavia oli yhteensä 13 henkilöä. Ryhmähaastatteluja oli neljä, joista kolmessa ryhmässä oli kolme henkilöä ja yhdessä kaksi haastateltavaa. Lisäksi teimme kaksi yksilöhaastattelua. Haastattelujen teemoja olivat kotouttamistyön menetelmät, haasteet ja mahdollisuudet. Aineiston keruu sijoittui kahden makunnan alueella sijaitseviin pienehköihin kaupunkeihin. Niissä ammattilaisten käsitykset saattavat olla hyvinkin erilaisia kuin suurissa kaupungeissa tai pienissä maalaiskunnissa (Jentsch \& Myriam 2009).

Aineisto analysoitiin aktiivisen kansalaisuuden toimintamahdollisuuksiin keskittyvällä sisällönanalyysilla (Ruusuvuori ym. 2010). Tarkastelemme järjestelmän tarpeiden ja maahanmuuttajien tarpeiden huomioimisen välisiä ristiriitoja. Sisällönanalyysin tuloksena aineisto jaettiin kolmeen luokkaan. Niistä ensimmäiseen kuuluvat aineistossa esiin tulevat ristiriidat työkansalaisuuden alueella ja toiseen ristiriidat perheasemaan liittyvän kansalaisuuden alueella. Kolmanteen luokkaan liitimme yleisemmällä tasolla havaitut ristiriidat aktiivisen kansalaisuuden toteutumisesta järjestelmän tarpeiden ja kotoutujien tarpeiden huomioimisen ristipaineissa. 
JÄRJESTELMÄN JA ASIAKKAIDEN TARPEIDEN VÄLINEN RISTIRIITA TYÖKANSALAISUUDESSA

Aineistossamme on runsaasti puhetta järjestelmän tarpeille rakentuvasta työkansalaisuudesta. Haastatteluissa painottuivat näkemykset, jotka nojaavat viime vuosikymmenten aikana tapahtuneeseen hyvinvointivaltiota koskevaan muutokseen, jonka myötä työntekoa on alettu pitää täyden kansalaisuuden ja autonomian mittapuuna. Analyysissämme näistä kansalaisuuden ulkoisista ehdoista puhutaan muun muassa seuraavasti ( $\mathrm{H}$ tarkoittaa haastateltavaa):

H: Me ollaan tämmönen järjestelmä- ja työvetonen kansa, mikä on totta kai itsestään selvä asia, eihän nyt yhteiskunta pyöri muuten (...) niin sit se osallisuus tulee monesti sen työn kautta ja koulutuksen kautta (...) saa välineitä siihen.

Aineistossa suomalaiset määritellään työkansalaisiksi, joille on tärkeää noudattaa järjestelmien vaatimuksia. Vastaavasti maahanmuuttajien kansalaisuutta rakennetaan koulutukseen ja työhön osallistumisen kautta. Tästä seuraa, että kotoutuminen ymmärretään koulutuspolulle ja työllistymiseen tarvittavien välineiden tarjoamisena. Ammattilaiset ymmärtävät työllistymisen olevan yhteiskunnalle välttämätöntä. Sitaatin puhuja ottaa itsestäänselvyytenä Hallituksen maahanmuuttopoliittisen ohjelman (Valtioneuvosto 2015) mukaisen ajattelun, jossa aikuisten maahanmuuttajien kotoutumisen edellytys on työllä hankittu toimeentulo. Myös Sotkasiira (2017) on havainnut, että järjestelmälähtöisessä kotouttamisessa syntyy taipumus puhua maahanmuuttajista taloudellisesta näkökulmasta ja sen mu- kaisesti kotouttamisesta resurssipolitiikkana.

Järjestelmälähtöisen kotouttamisen ja kotoutujan tarpeiden välistä ristiriitaa kuvataan aineistossa seuraavasti:

H: monia juttuja ohjaa ett työttömyystilaston pitäs olla nätimpi niin pannaan toimenpiteeseen (...) on vähän vähentyny nämä työttömät, mutta toisaalta eihän se oo se tilanne muuttunu miksikään sen ihmisen kohdalla. (...) nythän meille syötetään tuolta siis tältä poliittiselta taholta että nopeesti työelämään ja nopeasti opitaan kieli siellä työssäkin. Ei tapahu ihan silleen. Eikä tapahdu nopeesti. (...) ku heitetään sut vain jonneki työpaikkaan niin kyl sä opit sen. Mutta eihän se oo pelkästään se työkieli, mitä pitää osata.

Puhuja vastustaa rakenteiden tarpeista nousevaa järjestelmälähtöistä kotouttamistyötä, joka edellyttää ohjeistusten noudattamista vailla omaehtoista harkintaa. Järjestelmälähtöisyyden myötä kotouttamistyöstä tulee toimenpidekeskeistä, jolloin kotoutuja määrittyy passiiviseksi toimenpiteiden kohteeksi. Aineisto tukee siten Pajulan (2014, 20) esittämää näkemystä järjestelmän logiikalle ja sen tarpeille nojautuvasta aktivoinnista, joka lähtökohdiltaan sivuuttaa yksilöllisten tarpeiden ja olosuhteiden tunnistamisen ja yhteensovittamisen tärkeyden palvelujärjestelmässä.

H1: Meillä kaikki järjestelmät eivät oo vaan valmiita tähän. Että me ei olla ite siihen valmiita, (...) koet itse auttavasi kun tarjoat sille tätä vaikka loppujen lopuks se varmaan tyydyttää enemmän- 
kin sitä auttajaa. Ett siinä on vääränlainen motiivi.

H2: Me syötetään että eikö sun ois nyt hyvä siirtyä sinne, nuori jossain vaiheessa, että no voin mä siirtyä ja sitte jossain vaiheessa tuleeki se totuus, että no en mää oikeesti ois halunnu, mutt mulle vaan sanottiin.

Lainauksen puhuja tunnistaa ammattilaisten vääränlaiset motiivit järjestelmälähtöisenä nopean kotoutumisen ideaalina. Hänen mielestään ripeän ja kustannustehokkaan kotouttamisen kääntöpuoli on, että se sisältää rakenteita ja järjestelmää palvelevan työttömyystilastojen kaunistamisen. Aktivointi näyttäytyykin passivointina, jos kotoutujan toiveet ja tarpeet jäävät huomioimatta ja kotoutujaa ohjataan rakenteiden määrittämien tarpeiden mukaisesti.

Ammattilaiset tunnistavat myös järjestelmälähtöisen informaation tarjoamiseen ja ohjaukseen liittyvät ongelmat:

H1: Vaikka meillä olis tulkki mukana, kun me kerrotaan, että mitä tarkoittaa tämä meidän järjestelmä, niin kun ei meidän kantasuomalaisillekaan ensimmäisellä kerralla välttämättä mene perille tämä koko paletti. Niin se jää hyvin kevyeksi sitten niitten ohjaus ja neuvonta, että miten sä haet töitä, mitä tarkoittaa Suomen työlainsäädäntö. H2: Se jää asiakkaan vastuulle.

He näkevät yksittäiset tiedotustilaisuudet monimutkaisista asioista "kevyinä" ohjauksen ja neuvonnan välineinä. Informaation välittämiseen liittyvä kotouttamistyön velvoite täyttyy, mutta järjestelmän monimutkaisuus ja sen tarjoamat mahdollisuudet eivät ammattilaisten "tulkkaaminakaan" avaudu asiakkaalle. Aineistositaatissa tulee näkyväksi ristiriita kotouttamistyön käytäntöjen (kevyen ohjauksen) ja sen konkreettisen tavoitteen eli maahanmuuttajan työllistymisen välillä. Kotouttamistyö jää uuden selontekovelvollisuuden (Banks 2007) täyttämiseksi ja vastuu asioiden ymmärtämisestä, työn etsimisestä ja työ̈listymisestä jää kokonaan maahanmuuttajalle.

Seuraavassa lainauksessa sanoitetaan huoli työkansalaisuuteen ohjaamisesta kotoutumisajan jälkeen.

H: Joku ottais kopin, ne jotka löytävät työn, löytävät sen omin voimin, että heitä ei tarvitse ohjata taikka auttaa, mut juuri nää väliinputoajat siinä kolmen neljän vuoden jälkeen. Kuka käy heidän kanssa käsi kädessä etsimässä sitä työpaikkaa, kertomassa heille, että miten sää käyttäydyt, kun haet työpaikkaa, ett mikä on työn arvostus Suomessa, ett miten he ymmärtävät sen työnantajan asenteen. Ett tämä on mun mielestä keskeisin avain, koska työ on se, ansaitset rahaa, pärjäät omin voimin ja kaikkihan loppujen lopuks sitä tahtoo.

Kotouttamiseen käytettävissä oleva aika ei ole riittävä kaikkien maahanmuuttajien toimintamahdollisuuksien vahvistamiseen. Toinen toimintamahdollisuuksien este on maahanmuuttajien tietämättömyys työnantajien vaatimuksista ja odotuksista. Näin ollen kotouttamistyön tehtäväksi määrittyy sekä työkansalaisuuteen ohjaaminen että "oikeanlaiseen" työnhakuun perehdyttäminen. Lappalaisen (2017, 338) mukaan ammattilaiset saattavat 
ymmärtää ohjauksen normaalistavana ja sopeuttavana. Hänen analyysinsä osoittaa, että kotouttamispolitiikan tahtotila monikulttuurisena ideaalina ei toteudu byrokraattisissa käytännöissä, joissa kotoutujien toimintamahdollisuudet jäävät tunnistamatta. Toisaalta kapeasti työkansalaisuuteen nojaavassa järjestelmälähtöisessä kotouttamisessa saattaa käydä niin, että "valmis paketti" menee "mappi ööhon", kuten aineistossamme myös kuvattiin. "Valmis paketti" on kielikuva, jolla kuvataan ahkeria, motivoituneita ja kieltä osaavia kotoutujia erotuksena heistä, jotka tarvitsevat enemmän aikaa ja ohjausta toimintamahdollisuuksien vahvistamiselle. Maahanmuuttajien voi olla vaikea saada töitä ilman ammattilaisten väliintuloa:

H: Kyllä ne [työnantajat] ymmärtää tietynlaisen sosiaalisen vastuun, et ei ne haluais kieltäytyäkään. (...) Joskus on joutunut tehä vähän isommin töitä, että oon saanut sen jalan oven väliin ja joskus sitten se on tullu yllättävän helpostikin (...) Hän [työnantaja] sano et kun täällä ei esimerkiksi ihan tummaihoista kassaa. Jos joku joutuu kohtamaan siinä sitten. (...) Kukaan ei oikein uskalla ottaa sitä askelta ittensä takia ja ehkä sitten sen ihmisenkään takia. Jos et ole liian vieraan näköinen niin se varmaan ihan ok ja jos sä puhut suurin piirtein suomalaisittain, niin se on turvallista vielä.

Lainauksessa ammattilainen havaitsee ristiriidan, joka syntyy siitä, että työnantajilla on sosiaalista vastuuta, mutta he tästä huolimatta käyttäytyvät maahanmuuttajia syrjivästi, ikään kuin työelämän ehtoja varjellen. Puhujalle kotouttamistyö ei tarkoita vain järjestelmän ehtojen hyväksymistä, vaan hän haluaa tehdä enemmän: hän haluaa "viedä ensin oman jalkansa työnantajan oven väliin" ennen kuin voi lähettää maahanmuuttajan työnantajan puheille ja kohdistaa työnsä myös paikallisiin työnantajiin.

Ammattilaiset tunnistavat ristiriidan järjestelmälähtöisen, rakenteiden tarpeille nojautuvan ja työkansalaisuuden ideaalia tavoittelevan kotouttamistyön sekä asiakkaiden tarpeille perustuvan työn välillä. Järjestelmän tarpeille rakentuva selontekovelvollisuus ymmärretään ensisijaisesti työtä suuntaavana ohjeistuksena, ei niinkään uutena selontekovelvollisuutena, jossa onnistumista mitataan sen kautta, kuinka hyvin ohjeistuksia noudatetaan (Juhila 2009; Banks 2007).Työkansalaisuuteen ohjaavan kotouttamisen ongelmana näyttäytyy se, ettei siinä tunnisteta palveluiden käyttäjien kognitiivisia toimintamahdollisuuksia. Tällöin ei saavuteta edes perusautonomiaa (Aaltio 2013) eli sitä, että kotoutujat olisivat osallisia tulevaisuuttaan koskevissa päätöksissä. Samalla myös aktiivisen kansalaisuuden edellytykset jäävät toteutumatta.

\section{Perheasemaan litttyväN KANSALAISUUDEN RISTIRIIDAT}

Kansalaisuutta määritellään myös suhteessa perheasemaan. Nämä määrittelyt ovat usein sukupuolittuneita (Lister 2007). Siksi on tärkeä pohtia kotouttamiskäytäntöihin liittyviä ongelmia perheiden toimintamahdollisuuksien tukemisen näkökulmasta. Seuraavassa esimerkissä ammattilainen kuvaa kriittisesti, miten järjestelmä tunnistaa vain tietynlaiset perheet oikeina perheinä: 
H: Tää järjestelmä on ydinperhettä varten kaikki etuudet menee sen ydinperheen mukaan, ku maahanmuuttajaperhe tulee, siihen saattaa kuulua äiti, joka on 43 vee ja poika, joka on 25 vee ja tytär, joka on 22 vee ja vielä poika, joka on 20 ja tytär, joka on 18. Siellä on aikuisia ja halutaan asua yhdessä, niin tämä järjestelmä ei ota vastaan tämmösiä perheitä kovin mielellänsä, koska meiän asunnot ei oo sitä varten, eikä asumistukijärjestelmät, eikä mitkään nää etuudet, järjestelmä vaatis olemaan tietyn sorttinen, että mahtuu tänne, soljahtaa helposti mukaan.

Haastateltava tunnistaa ristiriidan, joka syntyy siitä, että perheiden tarpeet tunnistetaan, mutta järjestelmän asettamat ehdot ovat ristiriidassa niiden toteutumisen kanssa perheissä, joissa aikuiset lapset asuvat vanhemman kanssa. Pohjoismainen hyvinvointiyhteiskunta tukijärjestelmineen määrittelee perheen vanhemmista ja heidän alaikäisistä lapsistaan muodostuvaksi yksiköksi. Tämän takia mahdollisuuksia tarjotaan ydinperheille, kun taas perheen ulkopuoliset ja sisarusten väliset suhteet määrittyvät palvelujärjestelmän kannalta ongelmallisiksi (Vuori 2012).

Seuraavassa lainauksessa tarkastellaan kotiäitiyttä:

H1: Kotiäitiys ei ole meillä ammatti niin kuin se on heillä.

H2: Niin ja toinen on sit semmonen ryhmä, ketkä tulee niinku nuorempana, mut et jää saman tien sit justiin äitiyslomalle. Saattaa olla monta vuotta äitiyslomalla, eikä,ja sitten tulee ilmoittautumaan, ei ole mitään kielitaitoa. On ollu vaan siinä omassa yhteisössä ja se on yks iso porukka.
Aineistositaatissa tulee esille, että maahanmuuttajayhteisön merkitystä äitien hyvinvoinnille ja aktiiviseen kansalaisuuteen tähtäävien toimintamahdollisuuksiensa vahvistumiselle ei tunnisteta. Kotouttamisjärjestelmä ei myöskään tavoita pitkällä perhevapaalla hoivatyötä tekeviä vanhempia, minkä vuoksi he saattavat jäädä vaille mahdollisuutta vahvistaa toimintamahdollisuuksiaan. Oman yhteisönsä piirissä eläviä kotiäitejä kuvataan syyttävässä sävyssä "toisiksi", jotka eivät kuulu tasa-arvoisiin "meihin" (esim. Keskinen 2012). Myös Vuoren (2012, 261) havaintojen mukaan kotouttamistyön ammattilaiset näkevät kotiäitien tilanteen reflektoimattomasti ongelmana. Heidän tarpeitaan ei nähdä yhteiskunnallisesti tärkeänä kysymyksenä vaan pikemminkin sukupuoleen ja perheasemaan liittyvänä ongelmana. Työmarkkinoiden ulkopuolella tehdyllä hoivatyöllä ei ole selkeää asemaa Suomen kotouttamiskäytännöissä (emt., 262), vaikka hoiva on osaltaan myös kansallisten ja globaalien yhteiskuntapoliittisten toimenpiteiden ohjaamaa toimintaa (Jokinen \& Jakonen 2011, 137).

Tarve kotiäitien kotoutumiselle tunnistetaan, mutta heidän kansalaisuuden tekojaan ei tunnusteta eikä heidän toimintamahdollisuuksiaan tueta aktiivisesti. Pikemminkin heitä kohdellaan passiivisina sekä kotoutumisesta ja kansalaisuudestaan irrottautuneita äiteinä (ks. Nordberg 2015). Kotiäidit "toiseutetaan" kahdesti: ensin heidän ajatellaan olevan suomalaisen tasa-arvon ulkopuolisia "toisia", minkä jälkeen heille ei välttämättä suunnata kotouttamistoimenpiteitä. 
Kotiäitiyden toimintamahdollisuuksien vahvistamatta jättäminen on ristiriidassa kotouttamispolitiikan työkansalaisuutta korostavan peruslinjauksen kanssa. Pohjoismaisessa kotouttamiskeskustelussa perheen kotoutuminen on jäänyt työllistymiskeskustelun varjoon, vaikka esimerkiksi kotolaki (1386/2010) kannustaa huomioimaan koko perheen kotoutumisen. Nordbergin ja Wreden (2015) mukaan pohjoismainen hyvinvointivaltio onnistuu tukemaan maahanmuuttajia tulonsiirroilla, mutta epäonnistuu vallan ja tiedon uudelleenjakamisessa. Norjalaisen Anna Grødemin (2017) mukaan sosiaaliturvan on katsottu jopa olevan haitallista maahanmuuttajanaisten työllistymiselle. Hänen mukaansa poliitikkojen puhe tarpeesta heikentää maahanmuuttajien sosiaaliturvaa heijastelee uusliberalistisen kansalaisuuden vaatimuksia, koska sosiaaliturvauudistuksesta puhuttaessa ei kiinnitetä huomiota kotoutumiseen. Aineiston valossa kotiäitiys ei näytä täyttävän kotouttamistyön ammattilaisten aktiiviselle kansalaisuudelle asettamia edellytyksiä.

\section{KOTOUTUJAN TOIMINTAKYKY JA AKTIIVISEN KANSALAISUUDEN MAHDOLLISUUDET}

Aaltio $(2013,79)$ painottaa, että yksilöllisten tarpeiden ja kollektiivisen hyvinvoinnin onnistunut yhteensovittaminen edellyttää jatkuvaa vuorovaikutusta kaikkien kotouttamisprosessiin osallistuvien kesken. Seuraavassa lainauksessa kuvataan ammattilaisten rajallisia mahdollisuuksia tukea yksilökohtaista toimintakykyä:
H1: Kotosuunnitelmassahan hyvin kevyesti kysytään hakijalta oma arvio omasta terveydentilasta. Se on aina hyvä, erittäin hyvä tai normaali. Seuraava kysymys on, onko sinulla omasta mielestäsi tarvetta fyysiseen tai psyykkiseen kuntoutukseen. (...) Ei ole on polvi kipeä.

H2: Kerran oli semmonen tilanne että se poika rupes puhumaan. Niin mä vaan siitä sun työharjoittelusta nyt, ei se oo mun tehtävä.

H1: Niin ja sitten siinä pitää muistaa, että sehän on asiakkaasta lähtevä päätös. Hän on päättänyt ettei hän kerro. Mutta jossain vaiheessa vuosien varrella, ihminen on vain rakennettu niin, että se psyyke murtuu ja sitten ollaan sairaslomalla ehkä, no kymmenen vuoden aikajaksolla jossain vaiheessa.

Kahden työntekijän keskustelu osoittaa, että vaikka he osana kotoutumissuunnitelman laatimista tiedustelevat asiakkaidensa tarvetta kuntoutukseen, rajaavat he työnkuvaansa niin, ettei kuntoutuksen järjestämiseen katsota voitavan ottaa kantaa. Mikäli kotoutuja kuitenkin kertoo enemmän tarpeistaan, kuten tässä tapauksessa kävi, ei ammattilaisilla ole jatkotyöskentelyyn mahdollisuuksia. Siksi myös aineistossa oleva ammattilaisen kommentti siitä, että "oikeesti mietittäis yhteistyönä”, on välttämätön lähtökohta järjestelmän avautumiselle ja yhteiselle arviolle siitä, mikä on tarpeen ja mahdollista kunkin kotoutujan kohdalla. Aineisto-ote tukee Doyalin ja Goughin (1991) tekemiä havaintoja, joiden mukaan autonomian toteutuminen nivoutuu kognitiiviseen kyvykkyyteen, mielenterveyteen sekä ulkoisiin mahdollisuuksiin. Kognitiivisen autonomian toteutumista vaikeuttaa se, että suomalaisen palvelujärjestelmän 
termit, kuten psyykkinen kuntoutus, eivät avaudu asiakkaille, mikäli niitä ei selvitetä perin juurin. Esimerkiksi psyykkisen kuntoutuksen tarpeen arviointi on kotoutujan näkökulmasta haastava valintatilanne. Siinä hänen tulisi tietää, mitä eri termeillä tarkoitetaan, mihin tilanteisiin kuntoutusta voi ylipäätänsä saada ja mitä kuntoutus voisi omalla kohdalla tarkoittaa.

Kognitiivisen autonomian vahvistuminen kotoutumistilanteissa on hidas ja tutustumista vaativa monitahoinen prosessi, kuten seuraava ammattilaisten yhteinen keskustelu osoittaa:

H1: Aikalailla hidas se tutustumisvaihe (...). Ja mietitään sitten niitä omia vahvuuksia, ja mitä on tehny ja mitä haluais tehdä. Ja tietysti se riippuu nyt siitä, mikä se tavoite on. (...) Että meiän ei tarttis oman itsemme takia ohjata niitä nuoria sinne lähihoitajakoulutukseen, koska me tiedetään, että järjestelemällä ei oo rahkeita ja me ei uskota niitten ihmisten rahkeisiin, vaan me pystyttäis vastata siihen epäkohtaan jollakin tavalla. Ett tarjota sitä tukee, että ne pärjä. (...) Pitää aktiivinen olla [työntekijöiden] (...) Mun mielestä erityisryhmien suosiminen ei muutenkaan oo kauheen hyvällä tasolla. Kyllä sitä joutuu vaivaa näkemään.

$\mathrm{H} 2$ :Tosi moni on motivoituneita ja tähtäimet on tosi korkeella, että välillä pitää jo vähän sillain himmata, ei sun tarvii opiskella niin paljon, tulee se enemmän se pelko, että ne väsyttää ittensä.

H3: Se on hankala, että missä kohtaa unelmien alas ampuminen on realismia ja missä kohassa se on itsekkyyttä. Pitää tosi hyvin kyllä tuntee nuori, koska ei sitä ihan helposti voi sanoa, että tää ei oo mahollista. Mä en ainakaan usko siihen, etteikö se ois. Se työmärä vaan on hirveen iso ja se vie tosi kauan aikaa.

(...) Sitte pystyy niitä asioita peilata.

Asiakkaan ja ammattilaisten tutustuminen vie aikaa. Aikaa vaatii sekin, että kotoutujan tavoitteet, toiveet, olemassa oleva osaaminen ja mahdollisuudet sovitetaan toisiinsa. Toinen haastateltava esittää, että järjestelmälähtöisyys voi merkitä kotoutujan tavoitteiden realistista arviointia tai olla myös merkki siitä, ettei ihmisen kyvykkyyteen uskota. Ryhmäkeskustelussa päätellään, ettei henkilölle voida sanoa, etteivät hänen toiveensa olisi mahdollisia. Sitaatissa kotoutumisen arvioidaan edellyttävän vaivannäköä sekä järjestelmän ja yksilöiden toiveiden yhteensovittamista luovalla tavalla. Ajan lisäksi asiakkaan emotionaalisen ja kognitiivisen autonomian tukeminen vaatii aktiivista vuorovaikutusta luottamuksen rakentamiseksi. Siihen sisältyy myös vaatimus reflektoida tavoitteita ja mahdollisuuksia (myös Gateley 2014, 8). Ammattilaisten on reflektoitava käsityksiään siitä, kenen tarpeita vastaaviksi kommunikaatio tai kotouttamiseen liittyvät toimenpiteet rakennetaan.

Pitkittyneet traumakokemukset ja kidutuksen jälkeiset traumat muuttavat henkilön kykyä tiedon käsittelemiseen ja oppimiseen. Mielenterveyteen liittyvä autonomia nousee esille varsinkin kotoutumisen alkuvaiheessa, mikä käy ilmi seuraavasta lainauksesta:

H1: Monella on niitä omia painajaisia sieltä jostain menneisyydestä, sekin auttaa, että täällä niitä aletaan selvittää, päästään alkuun.

H2: Sit on niitä, jotka puhuu tosi avoimesti joko siitä tuloreitistä (...) saattaa 
olla, että vaikenee täysin, mä en halua puhua mitään. (...) sitten pitkän ajan päästä ne alkaa pulpahtelee pintaan ja aletaan huomioimaan, että et saa nukuttua tai oot masentunut.

Lainauksessa kuvataan erityisesti pakkomuuttajien kotouttamistyössä tärkeää mielenterveyteen liittyvien tarpeiden tunnistamista ja autonomian vahvistamista. Toisaalta ammattilaiset uskovat, että asiakkaalla on oikeus olla kertomatta kokemuksistaan. Berlin (2001) kuvaa liberaaliin demokratiaan kuuluvana piirteenä käsitystä, jonka mukaan henkilöillä täytyy olla henkilökohtaisen vapauden alue, jota viranomaiset eivät saa loukata. Aiempien elämänkokemusten vaurioittama kognitiivinen ja emotionaalinen autonomia tekee tästä vapauden alueesta erityisen haavoittuvan. Siksi pakkomuuttoon liittyvässä kotouttamistyössä juuri emotionaalisen ja kognitiivisen autonomian alueiden yhteenkietoutumisen tuntemus ja vahvistaminen on keskeistä. Esimerkiksi kidutustrauma saattaa rikkoa kognitiivisen $\mathrm{ja}$ emotionaalisen autonomian ja hankaloittaa luottamuksellisten suhteiden luomista uuden yhteiskunnan toimijoihin (Turtiainen 2011).

Yksilöllisille tarpeille rakentuvan ja järjestelmälähtöisen tasapäistävän kotouttamistyön välinen jännite muodostuu aineistossa myös resurssiajattelun kautta. Maahanmuuttajien resurssit saadaan yhteiseen käyttöön, mikäli varsinkin alkuvaiheen kotoutumispalveluissa "massatuotannon" sijaan tunnistetaan yksilöiden tarpeet ja annetaan heille niiden mukaista tukea (Sotkasiira 2018b). Tämä on myös kotoutumislain ja poliittisten linjausten (esim. Työ- ja elinkeinoministeriö 2013, 5) mu- kaista. Tämä näkemys konkretisoituu seuraavassa lainauksessa.

$\mathrm{H}$ : Meille on yhteiskunnallisesti suuri haaste, että miten me osataan hyödyntää se resurssi, mikä näissä ihmisissä tulee, et kulkee käsi kädessä tämän täysvaltaisuuden kanssa, että pääsee toimimaan niillä olemassa olevilla taidoilla ja kyvyillä, mitä on ja resursseilla mitä on. Ollaanko me valmiita myöskin ihan yksilöinä saatikka yhteiskuntana ja työelämänä ja koulutusmaailmana ottamaan vastaan se resurssi, että nää ihmiset pääsis mukaan täysivaltaisina. Mä aattelen, täysivaltaisuuteen liittyy ne välineet, millä täällä toimitaan, että on hallinnassa ne välineet.

Sitaatissa haastateltava tunnistaa kotoutujien kyvykkyyden ja näkee heidät resurssina yhteiskunnalle, mikä mahdollistaa kotoutujien ja yhteiskunnan tarpeiden yhteensovittamisen. Jotta tähän päästään, on eri osapuolilla oltava valmiutta ja taitoa nähdä kotoutujat yksilökohtaisine kyvykkyyksineen resurssina yhteisölle ja yhteiskunnalle. Parhaimmillaan sitaatissa mainitut "välineet ja täysivaltaisuus" ovat kriittistä autonomiaa, jolloin maahanmuuttajat luovat yhteiskunnallisen toiminnan edellytyksiä ja rakenteita aktiivisina kansalaisina. Kotouttamistyössä on irrottauduttava järjestelmälähtöisten tarpeiden täyttämisestä ja vahvistettava kotoutujien toimintamahdollisuuksia (Sen 1999, 53). Sen sisäinen logiikka ei asetu ongelmitta tulkintakehykseen, jonka nykyhetkessä vallitseva ymmärrys aktiivisesta kansalaisuudesta tarjoaa (Kantola \& Kananen 2013; Julkunen 2017). 


\section{LOPUKSI}

Artikkelissa huomion keskipisteenä olivat maahanmuuttajien autonomisten toimintamahdollisuuksien ja rakenteiden väliset jännitteet, joita tarkastelimme kotouttamistyötä tekevien ammattilaisten näkökulmasta. Havaitsimme, että kotouttamistyön rakenteisiin suuntautuva selontekovelvollisuus painottaa työkansalaisuutta. Ammattilaisten näkemysten mukaan maahanmuuttajien autonomiassa on kuitenkin kyse työkansalaisuutta laajemmasta kokonaisuudesta, jonka vahvistamiseen tarvitaan uusia välineitä ja työkaluja. Tarkastelumme toi esiin myös sen, etteivät edes odotetut työelämävalmiudet omaavat maahanmuuttajat työllisty työnantajien asenteiden takia. Näin ollen myös työelämä määrittyi kotouttamistyön kohteeksi. Työkansalaisuuden toteutuminen edellyttää kotoutumislain korostamaa kotouttamistyön kaksisuuntaisuutta, mikä ei kuitenkaan toteudu ilman aktiivista toimintaa.

Aineistomme valossa erityisesti kotiäitien perheasemaan perustuva kansalaisuus on vaikeasti saavutettavissa. Ensinnäkään järjestelmä ei tunnista kotiäitien tekemää hoivatyötä aktiivisen kansalaisuuden teoiksi eikä äitien omia yhteisöjä nähdä autonomiaa tukevina. Ammattilaiset eivät myöskään tunnista kotiäitien mahdollisuutta tasa-arvoon, mikä jättää äidit myös ulos muuten valtavirtaistetusta työkansalaisuuteen ohjaamisesta.

Aktiivisen kansalaisuuden mahdollisuuksien tarkastelussa painottuu maahanmuuttajien erityistarpeiden huomioiminen. Pitkä aika, luottamus, työntekijöiden kyky reflektoida omaa toimintaansa sekä yhteistyö eri toimijoiden kesken ovat emotionaalisen ja kognitiivisen autonomian vahvistamisen edellytyksiä. Aineistossamme lakien merkitys autonomian ulkoisten edellytysten mahdollistajina on toissijainen. Sen sijaan maahanmuuttajien autonomiaa tukevat työntekijöiden ammattitaito, oman toiminnan reflektointi sekä maahanmuuttajien tarpeiden tunnistaminen kotouttamisen lähtökohtana.

Ammattilaisten näkemyksissä painottuu ristiriita yhtältä kapeasti työkansalaisuudelle rakentuvan, sopeuttavan ja järjestelmän tarpeille rakentuvan kotouttamistyön ja toisaalta kotoutujien autonomiaa tukevan toimintamahdollisuuksia vahvistavan työn välille. Hyvinvointivaltion uuden politiikan (Eskelinen 2017; Julkunen 2017) mukaisesti maahanmuuttajien elämäntilanteita tarkastellaan työkansalaisuuden tuottamisen ja taloudellisen tehokkuuden kannalta.Vastaavasti ammattilaisten näkemyksissä tunnistetaan erityisesti pakkomuuttajina tulleiden, enemmän palveluja tarvitsevien maahanmuuttajien tarpeet sekä heidän kokonaisvaltaisen hyvinvointinsa kognitiiviset ja emotionaaliset tekijät (Doyal \& Gough 1991).

Ymmärrys kotouttamisesta kaventuu, kun kansalaisuutta tarkastellaan järjestelmälähtöisesti. Sitä kaventaa myös keskittyminen työkansalaisuuteen sekä talouden näkökulmiin (esim. Kokkonen 2016; Kivipelto 2018). Järjestelmän tarpeille rakennettu mahanmuuttajien sopeuttaminen kääntyy paradoksaalisesti itseään vastaan, sillä yksilöiden tarpeet eivät rakennu vain ulkoisten märirttelyjen varaan. Uskomme, että yksilöllisten tarpeiden tunnistamatto- 
muus ja huomiotta jättäminen passivoivat maahanmuuttajia. Maahanmuuttajat saatetaan pakottaa aloitekyvyttömyyteen ja palveluista riippuvaisiksi (myös Turtiainen 2012). Heiltä puuttuu mahdollisuus neuvotella tulevaisuudestaan edes perusautonomian tasolla, mikä muodostaa uhan heidän aktiiviselle kansalaisuudelleen.

\section{LÄHTEET}

Aaltio, Elina (2013) Hyvinvoinnin uusi järjestys. Helsinki: Gaudeamus.

Alitolppa-Niitamo, Anne \& Söderling, Ismo \& Fågel, Stina (2005) Olemme muuttaneet: näkökulmia maahanmuuttoon, perheiden kotoutumiseen ja ammatillisen työn käytäntöihin. Helsinki: Väestöliitto.

Banks, Sarah (2007) Between Equity and Empathy: Social Professions and the New Accountability. Social Work and Society 5 (3), 11-22.

Berlin, Isaiah (2001) Vapaus, ihmisyys ja historia. Helsinki: Gaudeamus.

Doyal, Len \& Gough, Ian (1991) A Theory of Human Need. Houndmills, Basingstoke, Hampshire \& London: Macmillan. https://doi.org/10.1007/978-1-34921500-3

Erel, Umut (2011) Reframing migrant mothers as citizens. Citizenship Studies 15 (6-7), 695-709. https://doi.org/10.1 080/13621025.2011.600076

Eskelinen, Teppo (2017) Tehostaminen ja ekonomismin politiikka. Teoksessa Teppo Eskelinen, Hannele Harjunen, Helena Hirvonen \& Eeva Jokinen (toim.) Tehostamistalous. Jyväskylä: SoPhi, 16-32.

Evers, Adalbert \& Guillemard, Anne-Marie (2013) Introduction: Marshall's concept of citizenship and contemporary welfare reconfiguration. Teoksessa Adalbert Evers \& Anne-Marie Guillemard (toim.) Social Policy and Citizenship. The Changing Landscape. Oxford: Oxford University Press, 3-34.

Gateley, Davina (2014) Becoming Actors of their Lives: A Relational Autonomy
Approach to Employment and Education Choices of Refugee Young People in London, UK. Social Work and Society $12(2), 1-14$.

Grødem, Anne (2017) Family-oriented policies in Scandinavia and the challenge of immigration. Journal of European Social Policy 27 (1), 77-89. https://doi. org/10.1177/0958928716673315

Heiskala, Risto (2006), Kansainvälisen toimintaympäristön muutos ja Suomen yhteiskunnallinen murros. Teoksessa Risto Heiskala \& Eeva Luhtakallio (toim.) Uusi jako. Miten Suomesta tuli kilpailukyky-yhteiskunta? Helsinki: Gaudeamus, 14-42.

Hiitola, Johanna \& Peltola, Marja (2018) Tuotettu ja koettu toiseus viranomaisten ja maahanmuuttajataustaisten vanhempien kokemuksissa. Teoksessa Johanna Hiitola, Merja Anis \& Kati Turtiainen (toim.) Maahanmuutto, palvelut ja Hyvinvointi - kohtaamisissa kehittyviä käytäntöjä. Tampere:Vastapaino, 124-145.

Isin, Engin (2008) Theorizing acts of citizenship. Teoksessa Engin Isin \& Greg Nielsen (toim.) Acts of citizenship. Lontoo: Palgrave Macmillan, 15-43.

Isin, Engin \& Turner, Bryan (2007) Investigating Citizenship: An Agenda for Citizenship Studies. Citizenship Studies 11 (1), 5-17. https://doi. org/10.1080/13621020601099773

Jentsch, Birgit \& Simard, Myriam (2009) Conclusion: Comparative Perspectives on Rural Immigrants' Integration. Teoksessa Myriam Simard \& Birgit Jentsch (toim.) International Migration and $\mathrm{Ru}-$ ral Areas. Lontoo: Routledge, 179-196.

Johansson, Håkan \& Hvinden, Børn (2007) What do we mean by active citizenship? Teoksessa Håkan Johansson \& Bjørn Hvinden (toim.) Citizenship in Nordic welfare states. Dynamics of choice, duties and participation in a changing Europe. Lontoo: Routledge, 32-49.

Jokinen, Eeva \& Jakonen, Mikko (2011) Rajaton hoiva. Teoksessa Eeva Jokinen, Jukka Könönen, Juhana Venäläinen \& Jussi Vähämäki (toim.) "Yrittäkää edes!" Prekarisaatio Pohjois-Karjalassa. Helsinki:Tutkijaliitto, 118-140.

Juhila, Kirsi (2009) Sosiaalityön selontekovelvollisuus. Janus 17 (4), 296-312. 
Julkunen, Raija (2017) Muuttuvat hyvinvointivaltiot. Eurooppalaiset hyvinvointivaltiot reformoitavina. Jyväskylä: SoPhi. Kansalaisuuslaki (359/2003).

Kantola, Anu \& Kananen, Johannes (2013) Seize the Moment: Financial Crisis and the Making of the Finnish Competition State. New Political Economy 18 (6), 811-826. https://doi.org/10.1080/1356 3467.2012.753044

Kerkkänen, Heikki (2008) Kotouttaminen kulturisoivan biopolitiikan käytäntönä. Finnish Journal on Ethnicity and Migration 3 (1), 21-33.

Keskinen, Suvi (2012) Kulttuurilla merkityt toiset ja universaalin kohtelun paradoksi väkivaltatyössä. Teoksessa Suvi Keskinen, Jaana Vuori \& Anu Hirsiaho (toim.) Monikulttuurisuuden sukupuoli. Kansalaisuus ja erot hyvinvointiyhteiskunnassa. Tampere: Tampereen yliopisto, 291-320.

Keskinen, Suvi (2017) Developing Theoretical Perspectives On Racialisation and Migration. Nordic Journal of Migration Research 7 (2), 64-69. https://doi. org/10.1515/njmr-2017-0018

Kivipelto, Minna (2018) Sosiaalityön asiantuntijuus suhteisiin paikantuvana politiikkana. Teoksessa Tarja Juvonen, Jari Lindh, Anneli Pohjola \& Marjo Romakkaniemi (toim.) Sosiaalityön muuttuva asiantuntijuus. Sosiaalityön tutkimuksen vuosikirja 2018. Rovaniemi: UNIpress, 18-38.

Kokkonen, Tuomo (2016) Sosiaalinen kansalaisuus kehittyvässä yhteiskunnassa. T. H. Marshallin sosiaalisia oikeuksia kansalaisuuskäsitys hyvinvointivaltiota koskevan keskustelun innoittajana. Jyväskylä studies in education, psychology and social research 557. Jyväskylä: Jyväskylän yliopisto.

Kotiranta, Tuija (2008) Aktivoinnin paradoksit. Jyväskylä: Jyväskylän yliopisto.

Kymlicka, Will \& Norman, Wayne (1994) Return of the Citizen: A Survey of Recent Work on Citizenship Theory. Ethics 104 (1), 352-381. https://doi. org/10.1086/293605

Laki kotoutumisen edistämisestä (1386/2010)

Laki vähemmistövaltuutetusta ja syrjintälautakunnasta $(751 / 2011)$.
Lappalainen, Pertti (2017) Kotouttamispolitiikkaa 2010-luvulla: osallisuusideaaleja ja mikroherruutta. Janus 25 (4), 334-341.

Linnanmäki-Koskela, Suvi (2010) Maahanmuuttajien työmarkkinaintegraatio. Vuosina 1989-93 Suomeen muuttaneiden tarkastelua vuoteen 2007 asti. Helsingin kaupungin tietokeskuksen tutkimuksia. Helsinki: Helsingin kaupungin tietokeskus.

Lister, Ruth (2007) Gendering Citizenship in Western Europe: New Challenges for Citizenship Research in a Cross-National Context. Bristol: Policy. https://doi. org/10.2307/j.ctt9qgzcn

Marshall, Tom (1992) Citizenship and Social Class. Lontoo: Pluto Press.

Nickerson, Angela \& Bryant, Richard \& Steel, Zachary \& Silove, Derrick \& Brooks, Robert (2010) The impact of fear for family on mental health in a resettled Iraqi refugee community. Journal of Psychiatric Research 44 (4), 229-235. https://doi.org/10.1016/j.jpsychires.2009.08.006

Nordberg, Camilla (2015) Invisibilised Visions - Migrant mothers and the reordering of citizenship in a Nordic welfare state context. Nordic Journal of Migration research 5 (2), 67-74. https://doi. org/10.1515/njmr-2015-0011

Nordberg, Camilla \& Wrede, Sirpa (2015) Street-Level Engagements: Migrated Families Encountering the Local Welfare State [Introduction], Nordic Journal of Migration Research 5(2), 54-57. https:// doi.org/10.1515/njmr-2015-0008

Närhi, Kati \& Kokkonen, Tuomo (2014) Transformation of Participation Policies and Social Citizenship in Finnish Welfare Governance. Teoksessa Aila-Leena Matthies \& Lars Uggehoj (toim.) Participation, Marginalisation and Welfare Services. Concepts, Politics and practices Across European Countries. Farnham: Ashgate, 95-112.

Pajula, Elina (2014) Tositarinoita osallisuudesta. Teoksessa Arja Jämsen \& Arja Pyykkönen (toim.) Osallisuuden jäljillä. Joensuu: Pohjois-Karjalan sosiaaliturvayhdistys ry, 11-21.

Peltola, Marja (2014) Kunnollisia perheitä. Maahanmuutto, sukupolvet ja yhteiskunnallinen asema. Helsinki: Nuorisotutki- 
musverkosto.

Pirkkalainen, Päivi \& Wass, Hanna \& Weide, Marjukka (2016) The political potential of migrants is often overlooked in discussions around integration. Jyväskylä: Yhteiskuntatieteiden ja filosofian laitos, Jyväskylän yliopisto.

Pyykkönen, Miikka (2007) Järjestäytyvät diasporat: Etnisyys, kansalaisuus, integraatio ja hallinta maahanmuuttajien yhdistystoiminnassa. Jyväskylä: Jyväskylän Yliopisto.

Rask, Shadia \& Castaneda, Anu \& Härkänen, Tommi \& Koponen, Päivikki \& Bergbom, Barbara, Toivanen, Minna \& Gould, Raija \& Koskinen, Seppo (2016) Työttömistä maahanmuuttajista suuri osa on työkykyisiä ja työhaluisia. Sosiaalilääketieteellinen Aikakauslehti 53 (1), 3-17.

Ruusuvuori, Johanna \& Nikander, Pirjo \& Hyvärinen, Matti (2010) Haastattelun analyysin vaiheet. Teoksessa Johanna Ruusuvuori, Pirjo Nikander \& Matti Hyvärinen (toim.) Haastattelun Analyysi. Tampere:Vastapaino, 9-36.

Saukkonen, Pasi (2013) Erilaisuuksien Suomi:Vähemmistö- ja kotouttamispolitiikan vaihtoehdot: Gaudeamus: Helsinki.

Sen, Amartya (1992) Inequality Reexamined. Oxford: Oxford University Press.

Sen, Amartya (1993) Capability and Well-Being. Teoksessa Martha Nussbaum \& Amartya Sen (toim.) The Quality of Life. Oxford: Oxford University Press, 30-53. https://doi. org/10.1093/0198287976.003.0003

Sen, Amartya (1999) Commodities and Capabilities. Oxford: Oxford University Press.

Sotkasiira, Tiina (2016) Maahanmuuttajanuoret - suomalaisen syrjäseudun toiveiden tynnyri? Teoksessa Antti Kivijärvi \& Marja Peltola (toim.) Lapset ja nuoret muuttoliikkeessä. Nuorten elinolot -vuosikirja 2016. Helsinki: Nuorisotutkimusseura, 181-196.

Sotkasiira, Tiina (2017) Inkluusiota kiihdyttämässä. Havaintoja kotouttamisen kentältä. Teoksessa Teppo Eskelinen, Hannele Harjunen, Helena Hirvonen, Eeva Jokinen (toim.) Tehostamistalous. Jyväskylä: SoPhi, 120-139.

Sotkasiira, Tiina (2018a) Integration, Finnish Somalis and Their Right to Every- day Life. Teoksessa Päivi Armila, Marko Kananen \& Yasemin Kontkanen (toim.) The Contexts of Diaspora Citizenship. Somali Communities in Finland and the United States. Cham: Springer International Publishing, 75-85.

Sotkasiira, Tiina (2018b) Kotoutumista vai hyvinvointia? Metafora-analyysi syrjäseutujen kotopalveluista. Teoksessa Johanna Hiitola, Merja Anis ja Kati Turtiainen (toim.) Maahanmuutto, palvelut ja Hyvinvointi - kohtaamisissa kehittyviä käytäntöjä. Tampere:Vastapaino, 30-52.

Suurpää, Leena (2002) Hyvää tahtoa vai hyvää vaihtoa? Maahanmuuttajien kotoutumisohjelmat solidaarisuuden valossa.Yhteiskuntapolitiikka 67 (1), 13-26.

Turner, Bryan (2001) The Erosion of Citizenship. British Journal of Sociology 52 (2), 189-209. https://doi. org/10.1080/00071310120044944

Turtiainen, Kati (2011) Riippuvuus pakolaisia vastaanottavassa sosiaalityössä. Teoksessa Aini Pehkonen \& Marja Väänänen-Fomin (toim.) Sosiaalityön arvot ja etiikka. Sosiaalityön tutkimuksen seuran vuosikirja. Jyväskylä: PS-kustannus, 139161.

Turtiainen, Kati (2012) Possibilities of Trust and Recognition between Refugees and Authorities - Resettlement as part of Durable Solutions to Forced Migration. Jyväskylä: Jyväskylän yliopisto.

Turton, David (2003) Conceptualizing forced migrants. RSC Working Paper No. 12. https://www.rsc.ox.ac.uk/files/ files-1/wp12-conceptualising-forcedmigration-2003.pdf Luettu 28.6.2018.

Työ- ja elinkeinoministeriö (2013) Kotoutumisen kokonaiskatsaus 2013. Työ- ja elinkeinoministeriön julkaisuja. TEM raportteja 38/2013. http://www.kotouttaminen.fi /fi les/39065/Kotouttamisen_Seurannan_kokonaiskatsaus.pdf Luettu 6.10.2018.

Ulkomaalaislaki (301/2004).

Valtioneuvosto (2015) Hallituksen maahanmuuttopoliittinen ohjelma.http://valtioneuvosto.fi/documents/10616/334517/ Hallituksen + maahanmuuttopoliittiset +toimenpiteet/186046e8-46c7-450c98cf-45b2e2d19c2c. Luettu 2.7.2018.

Wilmsen, Brooke (2013) Family Separation and the Impacts On Refugee Set- 
tlement in Australia. Australian Journal of Social Issues 48 (2), 241-262. https:// doi.org/10.1002/j.1839-4655.2013. tb00280.x

Vuori, Jaana (2012) Arjen kansalaisuus, sukupuoli ja kotouttamistyö.Teoksessa Suvi Keskinen, Jaana Vuori \& Anu Hirsiaho (toim.) Monikulttuurisuuden sukupuoli: kansalaisuus ja erot hyvinvointiyhteiskunnassa. Tampere: Tampereen yliopisto, 235-262.
Vuori, Jaana (2015) Kotouttaminen arjen kansalaisuuden rakentamisena. Yhteiskuntapolitiikka 80 (4), 395-404.

Yhdenvertaisuuslaki (1325/2014). 